\title{
Copper nanoparticles (CuNPs) increase the vase life of cut carnation and chrysanthemum flowers: antimicrobial ability and morphophysiological improvements
}

\author{
Nahid Rashidiani ${ }^{1}$, Farzad Nazari ${ }^{1 *}$, Taimoor Javadi ${ }^{1}$, Saadi Samadi ${ }^{2}$
}

\begin{abstract}
This research was carried out to evaluate the effects of copper nanoparticles (CuNPs) on the postharvest physiology of carnation and chrysanthemum cut flowers. Synthesized CuNPs were applied at 10 and $20 \mathrm{mg} \mathrm{L}^{-1}$ to both cut flowers by the pulsing method. The physicochemical characteristics and the activity of antioxidant enzymes were measured on 0, 3, 6 and 9 days along the vase life. According to heat map analysis, changes in measured parameters were affected by flower type $>$ vase period $>$ CuNPs concentration. Results also showed that treating the two species of cut flower with CuNPS by the pulse treatment improved the relative fresh weight (RFW), vase solution uptake (VSU), membrane stability index (MSI), flower diameter and total soluble carbohydrate (TSC). Meanwhile, a decrease in both bacterial population of the stem end and the hydrogen peroxide $\left(\mathrm{H}_{2} \mathrm{O}_{2}\right)$ was observed. In comparison with the control, CuNPs at $20 \mathrm{mg} \mathrm{L}^{-1}$ by pulse treatment almost increased the vase life in both cut flowers by $30 \%$.
\end{abstract}

Keywords: copper, Dendranthema grandiflorum, Dianthus caryophyllus, microbial growth, postharvest quality.

\section{Resumo}

Nanopartículas de cobre (CuNPs) aumentam a vida útil de vaso de flores de cravo e crisântemo cortadas: capacidade antimicrobiana e melhorias morfofisiológicas

Esta pesquisa foi realizada para avaliar os efeitos das nanopartículas de cobre (CuNPs) na fisiologia pós-colheita de flores de cravo e crisântemo. Foram aplicados 10 e $20 \mathrm{mg} \mathrm{L}^{-1} \mathrm{CuNPs}$ sintetizados em ambas as flores cortadas pelo método de pulse. As características físico-químicas e a atividade das enzimas antioxidantes foram medidas aos $0,3,6$ e 9 dias ao longo da vida útil de vaso. De acordo com a análise do mapa de calor, as alterações nos parâmetros medidos foram afetadas pelo tipo de flor $>$ período no vaso > concentração de CuNPs. Os resultados também mostraram que o tratamento das duas espécies de flores cortadas com CuNPS pelo tratamento por pulso melhorou o peso fresco relativo (RFW), captação da solução do vaso (VSU), índice de estabilidade da membrana (MSI), diâmetro da flor e carboidrato solúvel total (TSC). Enquanto isso, foi observada uma diminuição na população bacteriana da extremidade do caule e no peróxido de hidrogênio $\left(\mathrm{H}_{2} \mathrm{O} 2\right)$. Em comparação com o controle, CuNPs a $20 \mathrm{mg} \mathrm{L}^{-1}$ por tratamento por pulso quase aumentou a vida do vaso em ambas as flores cortadas em $30 \%$.

Palavras-chave: cobre, Dendranthema grandiflorum, Dianthus caryophyllus, crescimento microbiano, qualidade pós-colheita.

\section{Introduction}

Various studies have reported inconsistent results that indicate copper $(\mathrm{Cu})$ salts cause either positive, negative or neutral effects on the vase life of different cut flower species (Halevy and Mayak, 1981). Van Meeteren et al. (1999) observed that one of the positive effects of tap water on the vase life of flowers may be due to the presence of the low concentration of $\mathrm{Cu}^{+2}$ ions. Celikel et al. (2011) also found that $\mathrm{Cu}$ sulfate $\left(\mathrm{CuSO}_{4}\right)$ at $2 \mathrm{mM}$ can assist in reducing the blockage of the xylem, and hence improvements in the relative fresh weight (RFW), vase solution uptake (VSU) and vase life of Acacia holosericea and Chamelaucium uncinatum flowers.

In addition to antibacterial properties, the pulsing of $\mathrm{Cu}^{+2}$ ion can be used for regulating the activity of enzymes that organize the occlusion caused by the wound. This, in turn, acts to postpone the wilting of the flowers, which has

${ }^{1}$ University of Kurdistan, College of Agriculture, Department of Horticultural Science, Sanandaj, Iran. *Corresponding author: f.nazari433@gmail.com ${ }^{2}$ University of Kurdistan, Faculty of Science, Department of Chemistry, Sanandaj, Iran. 
been the case observed in chrysanthemums and Bouvardia (van Doorn and Vaslier, 2002; Vaslier and van Doorn, 2003). Low concentrations of $\mathrm{Cu}^{+2}$ may retard the activities of peroxidase (POD) (Kim et al., 1996). In particular, $\mathrm{Cu}$ sulfate controls the activity of POD and phenol oxidized enzymes (van Doorn and Cruz, 2000; Celikel et al., 2011). Loubaud and van Doorn (2004) also indicated that the pulsing of $\mathrm{CuSO}_{4}$ at $2 \mathrm{mM}$ or as in vase solution at 0.25 and $0.5 \mathrm{mM}$ can delay the wilting of roses, astilbe, and viburnum, as a result of antimicrobial properties and the inhibitory effects on oxidative enzymes.

$\mathrm{Cu}^{+2}$ ions can alleviate the occurrence of woundinduced xylem occlusion at the end of the flowering stem of chrysanthemum cv. Vyking (Van Doorn and Vaslier, 2002). In addition, Ratnayake et al. (2011) reported that pulsing or as continuous treatments of $\mathrm{Cu}^{2+}$ salts at $2.2 \mathrm{mM}$ or $0.5 \mathrm{mM}$, respectively can lead to an extended vase life compared to deionized water (DIW). SharifZadeh et al. (2013) used $\mathrm{Cu}$ sulfate as a $5 \mathrm{~h}$ pulse at $6 \mathrm{mM}$ in Lisianthus, whereby the vase life became longer as a result of higher VSU and RFW values and lower POD and superoxide dismutase (SOD) activities. Otherwise, Ratnayake et al. (2012) found that the prominent mechanism by which $\mathrm{Cu}^{+2}$ ions positively affect the vase life of $A$. holosericea is not related to antibacterial properties.

Carnation and chrysanthemum are two popular cut flowers with short vase life in the international trade market of cut flowers. To the best of our knowledge, there is no report about the effects of CuNPs on features that comprise the particularities of the postharvest management of cut flowers. Therefore, in this study, synthetic CuNPs were used to gauge their effectiveness in improving the postharvest management of these flowers.

\section{Materials and methods}

\section{Synthesis of CuNPs}

To prepare CuNPs, $0.4 \mathrm{~g} \mathrm{CuCl}_{2}$ was initially dissolved in $100 \mathrm{~mL}$ of distilled water. This was followed by a slow addition of ascorbic acid solution to the reaction mixture. The mixture of reaction was stirred at $90{ }^{\circ} \mathrm{C}$ until color of the solution shifted gradually to yellow, orange, brown and eventually dark brown-black (Umer et al., 2014). Then the morphology, shape and size of synthesized of CuNPs were considered by scanning electron microscopy (SEM) (FESEM, MIRA3 TESCAN, Czech Republic). It is exhibited that CuNPs have a size of about 15-73 nm (Figure 1).

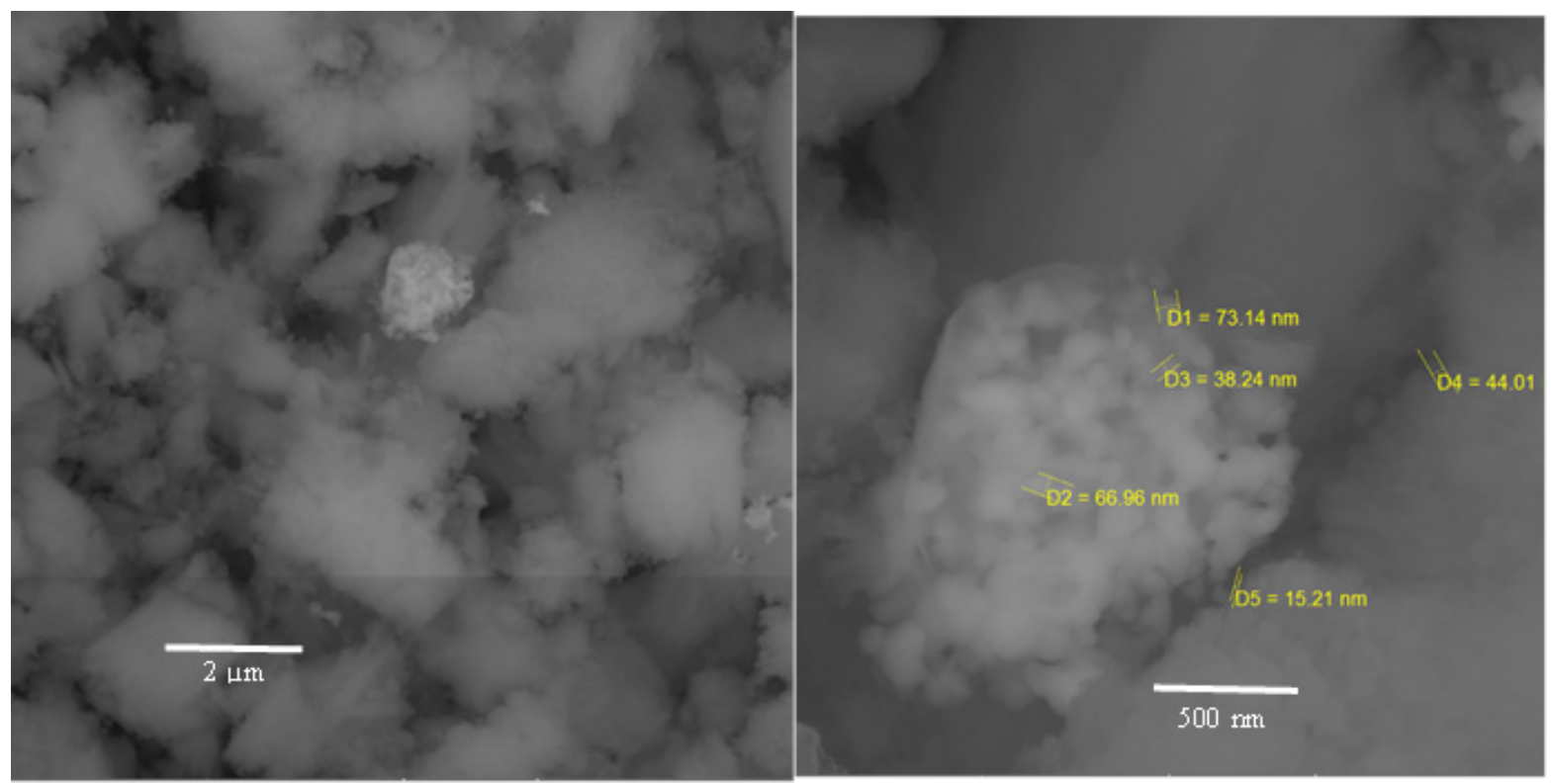

Figure 1. The SEM image of CuNPs.

Preparing cut flowers and application of treatments

At the commercial harvesting stage, the cut flowers of carnation (Dianthus caryophyllus cv. Yellow Viana) and chrysanthemum (Dendranthema grandiflorum cv. Boris Becker Sunny) were collected from a soillesscultured greenhouse. The stems were cut right away to shorten the stem length to $40 \mathrm{~cm}$. Apart from 3-4 leaves on the top of each stem, all other leaves were removed. Then, the pulsing method was used for applying the CuNPs at two concentrations of 10 and $20 \mathrm{mg} \mathrm{L}^{-1}$ for $24 \mathrm{~h}$. Deionized water (DIW) containing $4 \%(\mathrm{w} / \mathrm{v})$ sucrose was poured into the vases $(300 \mathrm{~mL})$ and maintained until the experimental completion, where the flowering stems were individually placed. To prevent the vase solution from being contaminated, and to control evaporation, pieces of aluminum foil were used for sealing the vase opening. At regular intervals, i.e., after $0,3,6$ and 9 days following the treatments, all parameters were measured, although the vase life could not be judged until the end of the experiment. The pulsing treatments and vase life were evaluated at $23 \pm 2{ }^{\circ} \mathrm{C}$, $50 \% \pm 10 \% \mathrm{RH}$ and $12 \mathrm{~h}$ of $15-20 \mu \mathrm{mol} \mathrm{m}^{-2} \mathrm{~s}^{-1}$ irradiance from cool-white fluorescence lamps. 


\section{Measurements}

\section{Vase life}

The number of days from the beginning of the experiment was counted until $50 \%$ of the flowers had wilted, which is used as a measure of the vase life for both types of cut flowers. The vase life in carnations was considered as finished when there was a browning of more than one-third of petals and the in-rolling of petals (Naing et al., 2017). In chrysanthemum, however, the wilting and yellowing of $50 \%$ of the petals marked the end of the vase life (Carrillo-López et al., 2016).

\section{Bacterial population of stem end}

Peptone water was used for diluting $1 \mathrm{~g}$ of the stem end after it was crushed and homogenized. The dilution continued until reaching a concentration of $10^{-3}$. Then, Petri dishes were prepared into which $1 \mathrm{~mL}$ of the solution was poured. Each Petri dish also received a $10 \mathrm{~mL}$ sterilized plate agar medium. The mixture was gently stirred for 5 to 10 seconds. An incubator was programmed at a temperature of $32^{\circ} \mathrm{C}$ where the Petri dishes remained for 2 days. Then, the bacterial colonies were counted based on $\log \mathrm{CFU} \mathrm{g}{ }^{-1}$ (Balestra et al., 2005; Liu et al., 2009).

\section{Vase solution uptake (VSU)}

The containers were weighed daily, with and without the flower shoots. The VSU was calculated according to an established formula: VSU $\left(\mathrm{mg} \mathrm{g}^{-1}\right.$ stem $\left.\mathrm{FW}\right)=\left(\mathrm{S}_{\mathrm{t}-1}-\mathrm{S}_{\mathrm{t}}\right)$; where $S t$ is the weight of vase solution $(\mathrm{g})$ at $t=$ day $0,3,6$ and 9, while $\mathrm{S}_{\mathrm{t}-1}$ is the weight of the vase solution $(\mathrm{g})$ on the previous day (He et al., 2006; Lu et al., 2010).

\section{Relative fresh weight ( $R F W)$}

The flowering stems were weighed to calculate the RFW every three days. A common formula was used accordingly (He et al., 2006):

\section{RFW (\%) $=\frac{W t}{W t 0} \times 100$}

Where, $\mathrm{W}_{\mathrm{t}}$ is the weight of the stem $(\mathrm{g})$ at $\mathrm{t}=$ day 0,3 , 6 , and 9 , while the $\mathrm{Wt}_{0}$ is the weight of the same stem $(\mathrm{g})$ at $\mathrm{t}=$ day 0 .

\section{Stem and flower diameter}

Three cross-sections were considered for measuring the stem diameter. These comprised under the peduncle, the middle and end of the stem. Two directions also were used in measuring the flower diameter. The values were reported as the average, and the measurements occurred every three days.

\section{Hydrogen peroxide $\left(\mathrm{H}_{2} \mathrm{O}_{2}\right)$}

An amount of $0.2 \mathrm{~g}$ of petal added to $2 \mathrm{~mL} 5 \%$ trichloroacetic acid (TCA) in a mortar and then ground. Each extract was centrifuged (Hettich, Germany) at 10,000 $\mathrm{g}$ for $5 \mathrm{~min}$. Then, $100 \mu \mathrm{L}$ of the supernatant solution was mixed with $100 \mu \mathrm{L}$ of $100 \mathrm{mM}$ phosphate buffer and 800 $\mu \mathrm{L}$ of $1 \mathrm{M}$ potassium iodide. Finally, spectrophotometer (Unico UV-2100, USA) was employed for reading the absorption of samples at $390 \mathrm{~nm}$ (Alexieva et al., 2001).

\section{Membrane stability index (MSI)}

Accordingly to Sairam et al. (2002), $0.1 \mathrm{~g}$ of petal discs were thoroughly washed in running tap water and were immersed in $2 \mathrm{~mL}$ of distilled water in two sets. One set was then placed in a warm water bath (HYSC WD-11B, Korea) at $40{ }^{\circ} \mathrm{C}$ ) for $30 \mathrm{~min}$ and electrical conductivity (EC) of the solution was measured with EC meter $(C 1)$. Then, the second set was placed in a boiling water bath at $100{ }^{\circ} \mathrm{C}$ for $20 \mathrm{~min}$ and its EC was measured as above $(C 2)$. Finally, the MSI was calculated as:

$$
M S I=\left(1-\frac{C 1}{C 2}\right) \times 100
$$

\section{POD enzyme activity}

For the measurement of POD activity based on Hemeda and Kelin (1990), an ice bed is first prepared in which 40 $\mu \mathrm{L}$ of $1 \%$ glycol and $40 \mu \mathrm{L}$ of $0.3 \% \mathrm{H}_{2} \mathrm{O}_{2}$ are included to be mixed with $400 \mu \mathrm{L}$ of $50 \mathrm{mM}$ potassium phosphate buffer. This solution is immediately loaded with $65 \mu \mathrm{L}$ of protein extract. Within a wavelength of $470 \mathrm{~nm}$, the spectrophotometer was used for evaluating the changes in light absorption at $120 \mathrm{~nm}$.

\section{SOD enzyme activity}

SOD exhibits specific levels of activity which is measurable by the Beyer and Fridovich (1987) method in which diverse types of chemicals are employed. This involves mixing $25 \mathrm{~mL}$ of $50 \mathrm{mM}$ phosphate buffer with 3.5 mg of $9.9 \mathrm{mM}$ L-methionine, $7.5 \mu \mathrm{l}$ Triton X-100 and $4 \mathrm{mg}$ of $57 \mu \mathrm{M}$ NBT. The solution is thus used for the reaction. Then, $10 \mu \mathrm{M}$ riboflavin and $20 \mu \mathrm{L}$ of protein extract were blended with one $\mathrm{mL}$ of the reaction mixture. These were collectively shaken for $10 \mathrm{~min}$. A shaker was used for this purpose which was placed at a distance of $30 \mathrm{~cm}$ from a 20 watt fluorescent lamp. Then, a spectrophotometer assisted in measuring the light absorption at $560 \mathrm{~nm}$.

\section{Total soluble protein (TSP)}

Based on Bradford's (1976) method, $0.5 \mathrm{~g}$ of petal tissue samples were crushed by liquid nitrogen and 0.25 $\mathrm{mg}$ of polyvinylpyrrolidone (PVP). While stirring the solution, $1.5 \mathrm{~mL}$ of potassium phosphate buffer $(\mathrm{pH} \mathrm{7})$ containing sodium metabisulfite was added. This solution was then added to grinded the petal samples and containing tubes were continually shaking until it became completely homogenized. The mixture was then centrifuged at 10,000 $\mathrm{g}$ for $20 \mathrm{~min}$ at the temperature of $4{ }^{\circ} \mathrm{C}$. Fifty $\mu \mathrm{L}$ of the extract was mixed again with $950 \mu \mathrm{L}$ Bradford solution to measure the protein concentration. After $15 \mathrm{~min}$, the solution absorbance was read at $595 \mathrm{~nm}$ of wavelength. 
Total soluble carbohydrate (TSC)

Following established procedures, liquid nitrogen was used for crushing $0.5 \mathrm{~g}$ of petal tissue. This was loaded with $5 \mathrm{~mL}$ of $95 \%$ ethanol, whereby uniform extracts were obtained and required centrifuging the supernatant extract at $3,500 \mathrm{~g}$ for $10 \mathrm{~min}$. Then, $3 \mathrm{~mL}$ of anthrone was added to 1 $\mathrm{mL}$ of this extract, which was collectively relocated inside a boiling water bath at $100^{\circ} \mathrm{C}$. After $10 \mathrm{~min}$, this temperature contributed to the creation of a colored phase. Subsequently, after cooling their absorption was read at $625 \mathrm{~nm}$. A standard curve was illustrated by using glucose as a reference. This curve served as a means of expressing the amount of TSC accordingly $\mathrm{mg} \mathrm{g}^{-1}$ of $\mathrm{FW}$ in petals (Irigoyen et al., 1992).

\section{Statistical analysis}

Based on a completely randomized design (CRD), the experiments were conducted as a factorial with three factors including two cut flowers, CuNPs at three levels (10 and 20 $\mathrm{mg} \mathrm{L}^{-1}$ along with the DIW) and four vase period $(0,3,6$ and 9 days). Five cut flower stems were included in each replication, and there were three replications in general. In measuring the vase life as a function of DIW (control) and each CuNPs treatment (10 and $\left.20 \mathrm{mg} \mathrm{L}^{-1}\right)$, the cut flowers were maintained in their corresponding vase solutions until they wilted. The mean values were compared via the LSD test $(p \leq 0.05)$, during the process of which the SAS software was employed. In addition, a heat map of parameters was constructed through the heat map package in the $\mathrm{R}$ environment, was used for a better evaluation of the changes of all characteristics except vase life under the interaction effect of three mentioned factors.

\section{Results and Discussion}

\section{Heat map analysis}

Based on a heat map analysis (Figure 2), all measured parameters, except vase life, were categorized into four groups in response to the interaction effect among three factors: two cut flowers, CuNPs at three levels (10 and 20 $\mathrm{mg} \mathrm{L}^{-1}$ along with the DIW) and four vase period $(0,3,6$ and 9 days). In fact, these four groups are based on flower type differences, and this indicates that the flower type has a substantial role in the changes of parameters. In general, the importance of three mentioned factors on classifying of parameters were as follows: flower type $>$ vase period $>$ CuNPs concentration (Figure 2).

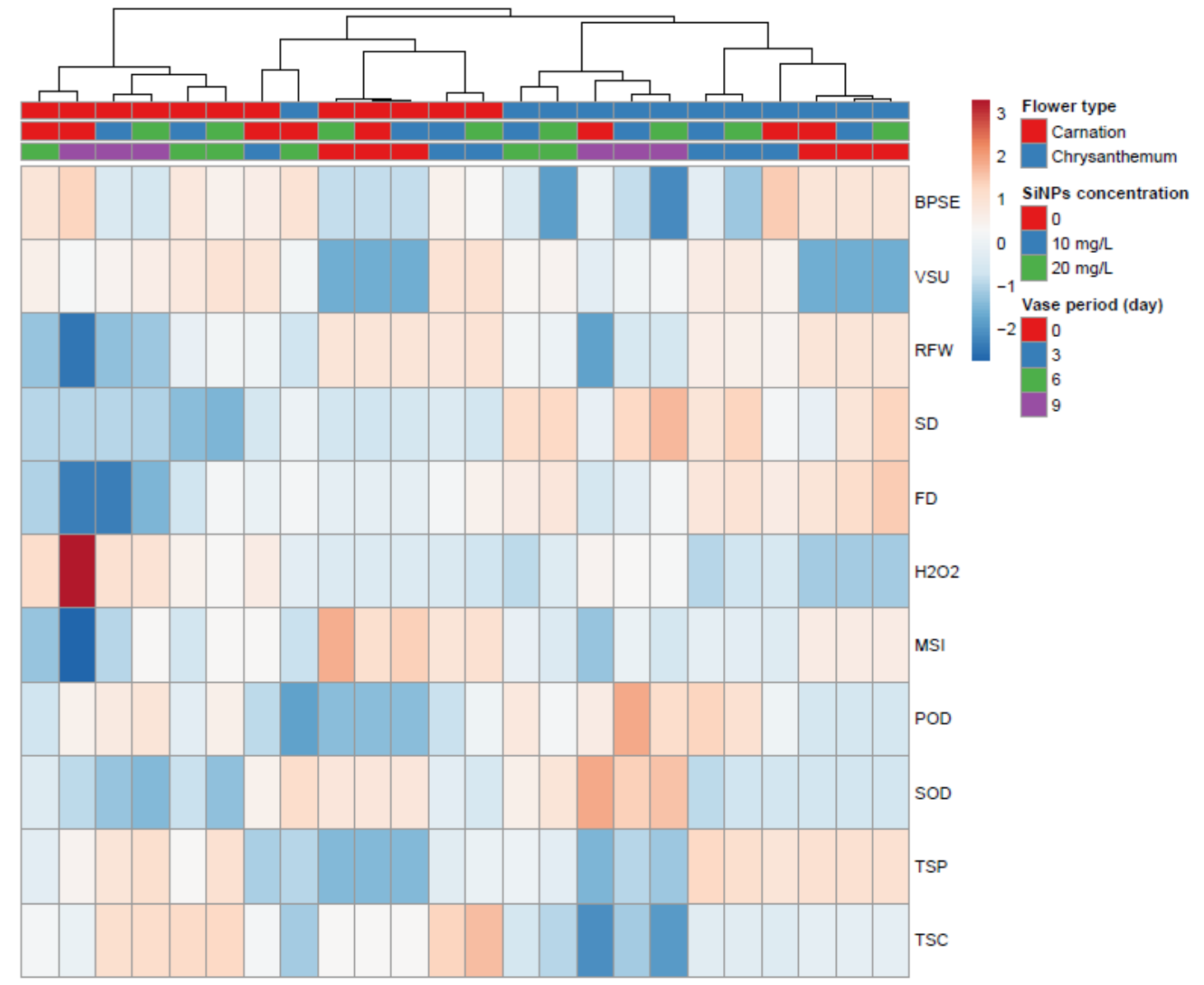

Figure 2. The heat map of all parameters influenced by interaction effect of three factors including two cut flowers, CuNPs at three levels (10 and $20 \mathrm{mg} \mathrm{L}^{-1}$ alongside to the DIW), and four sampling times (0, 3, 6 and 9 days). [BPSE, bacterial population of stem end; VSU, vase solution uptake; RFW, relative fresh weight; SD, stem diameter; FD, flower diameter; $\mathrm{H}_{2} \mathrm{O}_{2}$, hydrogen peroxide; MSI, membrane stability index; POD, peroxidase; SOD, superoxide dismutase; TSP, total soluble protein, and TSC, total soluble carbohydrate]. 


\section{Vase life of two cut flowers}

The sum of effects caused by CuNPs led to a prolonged vase life for both cut flowers. The most extended vase life resulted from the application of CuNPs at $20 \mathrm{mg} \mathrm{L}^{-1}$. In both cut flowers, the concentration of $10 \mathrm{mg} \mathrm{L}^{-1}$ did not cause any significant differences when compared with the control. A significant difference was caused by $20 \mathrm{mg} \mathrm{L}^{-1}$ in carnation, but not in chrysanthemum (Figures $3 a$ and $3 b$ ).
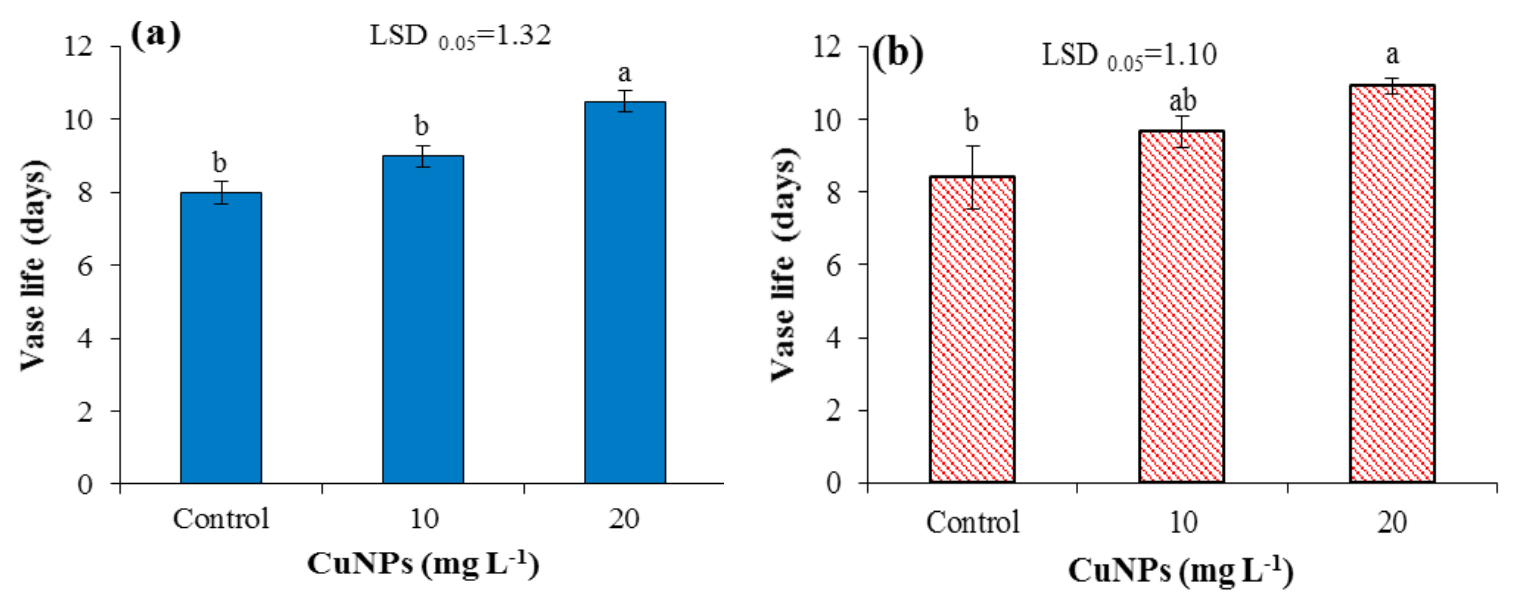

Figure 3. Effect of two concentrations of CuNPs $\left(10\right.$ and $\left.20 \mathrm{mg} \mathrm{L}^{-1}\right)$ alongside the control (DIW) on vase life of carnation (a) and chrysanthemum (b). Values represent means \pm standard error ( $\mathrm{n}=3$ ). Least significant difference (LSD) at $\mathrm{P} \leq 0.05$ was used for means comparison.

As explained, after the flowers are harvested from their mother plant, they enter a senescence process. This issue is accelerated by several factors such as water stress (Sankat and Mujaffar, 1994), carbohydrate depletion, and contamination by microorganisms and ethylene (Witte and van Doorn, 1991). Our results on the improvement of vase life by $\mathrm{Cu}$ compounds are supported by previous studies on different flowers such as chrysanthemum (Van Meeteren et al., 1999; van Doorn and Vaslier, 2002), bouvardia (van Doorn and Vaslier, 2003), rose, astilbe and viburnum (Loubaud and van Doorn, 2004), Chamelaucium uncinatum (Celikel et al., 2011), A. holosericea (Celikel et al., 2011; Ratnayake et al., 2011, 2012).

\section{Bacterial population of stem end}

The bacterial population of the stem end increased in control and in the carnation during the vase period. An exceptional result, however, was obtained in chrysanthemum, the bacterial population of the stem end of which increased until the $3^{\text {rd }}$ day but was then followed by a decrease. The application of CuNPs inhibited the growth of bacterial population of the stem end in both cut flowers, especially in chrysanthemum. By the $9^{\text {th }}$ day of the vase period, both concentrations of CuNPs had managed to cause a significant effect on carnation in terms of the bacterial population of the stem end, as compared with the control. In the vase solution of chrysanthemum, the application of both concentrations of CuNPs, especially the $20 \mathrm{mg} \mathrm{L}^{-1}$, caused a significant decrease in the growth of the bacterial population of the stem end throughout the vase period (Figure $4 \mathrm{a}$ ).

This difference in the growth pattern of bacterial populations on the stem end of the two flowers may be due to the type of phenolic compounds that are secreted from the stem end into the vase solution. Phenolic secretions may have been more in chrysanthemum than in carnation. Phenolic compounds are secondary metabolites that are involved in plant defense against pathogens (Naczk and Shahidi, 2004). Reports indicate that the inclusion of $\mathrm{Cu}$ in vases contributes to the release of $\mathrm{Cu}^{+2}$ ions into the vase solution, thereby prompting antimicrobial activity. It has also been reported that the antibacterial properties of compounds containing $\mathrm{Cu}$ element are due to: (1) disruption of biochemical processes by their interaction with biomolecules such as DNA and proteins (Raffi et al., 2010), (2) destruction of the plasma membrane integrity (Avery et al., 1996), (3) oxidative damages inflicted on bacterial cells by the creation of ROSs (Tran and Mallik, 2010) and (4) changes in the expression of some apoptosis genes which cause bacterial cell death (Sun et al., 2012).

\section{VSU and RFW}

From the beginning of the vase period to the $3^{\text {rd }}$ day, there was an increase in the amount of VSU of the control group in both flowers. However, this was followed by a drastic decrease until the $9^{\text {th }}$ day. The amounts of VSU in flowers treated with CuNPs were higher than the control, and the trend of its decline was less sharp in the treated flowers during the vase period. On the $9^{\text {th }}$ day of the vase period, a significant difference was observed in comparison with the control due to the effects of CuNPs at $20 \mathrm{mg} \mathrm{L}^{-1}$ on carnation and those of CuNPs at 10 and $20 \mathrm{mg} \mathrm{L}^{-1}$ on chrysanthemum (Figure 4b).

During the vase period, both cut flowers showed a decrease in their amounts of RFW. The rate of this decrease was higher in carnation than in the chrysanthemum. 
Meanwhile, the use of CuNPs caused significant maintenance of RFW in both flowers. For the carnation and chrysanthemum, respectively, the levels of 20 and $10 \mathrm{mg}$ $\mathrm{L}^{-1}$ CuNPs caused better effects than other concentrations on the maintenance of RFW, although there were no significant differences between them in both flowers. On the $9^{\text {th }}$ day of the vase period, using both concentrations of CuNPs on both cut flowers led to higher values of RFW in comparison with the control (Figure 4c).

It is well established that, in cut flowers, RFW declines through the storage time and that the rate of loss is proportionate to the number of days from harvest (Reid and Jiang, 2012). By placing the cut flower stems in the vase solution during the days of the vase period, the obstruction of the xylem vessels becomes an inevitable outcome due to air embolism (cavitation), the presence of microorganisms, or the formation of phenolic compounds which make the absorption of water difficult by the plant, and thus vase life is reduced (van Doorn and Cruz, 2000; van Doorn and Vaslier, 2002; Loubaud and van Doorn, 2004; Celikel et al., 2011; Ratnayake et al., 2011).

In our study, CuNPs reduced the growth of bacterial populations on the stem end in the two cut flowers (Figure 4a). It can be argued that this is the main reason why the RFW and VSU values are improved. These improvements were obtained by $\mathrm{Cu}^{2+}$ salts at $0.5 \mathrm{mM}$ in A. holosericea (Ratnayake et al., 2011), $\mathrm{Cu}$ sulfate at $2 \mathrm{mM}$ in Ch. uncinatum (Celikel et al., 2011) and at $6 \mathrm{mg}$
$\mathrm{L}^{-1}$ in Eustoma grandiflorum (Sharifzadeh et al., 2013). In this context, Van Meeteren et al. (1999) reported that the RFW of D. grandiflorum Tzvelev cv. Cassa flowers improved by placing the flower stems in a vase solution containing $\mathrm{CuSO}_{4}$, mentioning that this effect is related to the antibacterial nature of $\mathrm{Cu}$.

\section{Changes in the stem and flower diameter}

The diameters of the stems and flowers were less affected by CuNPs. Changes to the stem diameter in treated and untreated carnations were not significant (data not shown). Contrary to this, both concentrations of CuNPs in chrysanthemum resulted in a significant increase in flower diameter compared to the control, although the concentration of $20 \mathrm{mg} \mathrm{L}^{-1}$ proved to be more appropriate (Figure 4d).

Similar to the stem diameter, the flower diameter of untreated flowers decreased during the vase period. This decrease occurred more drastically in carnation than in chrysanthemum. The application of CuNPs maintained the flower diameter, although it amounted to no significance on the $9^{\text {th }}$ day of the vase period (Figure 4d). In agreement with our results on the decrease of flower diameter, Dar et al. (2014) reported that flower diameter in D. chinensis first increased and then finally declined during the development and senescence processes. As senescence progresses because of the loss of petal turgidity, the flaccid occurrence of cells is accompanied by the decline of flower diameter (Ahmad and Tahir, 2016).

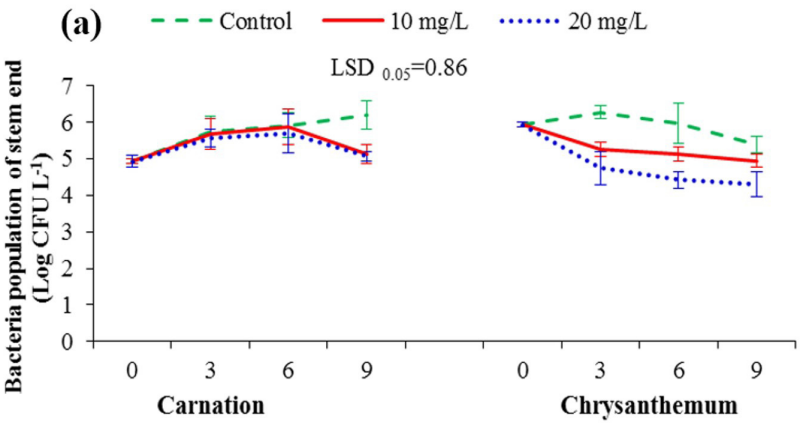

Vase period (days)

(c)

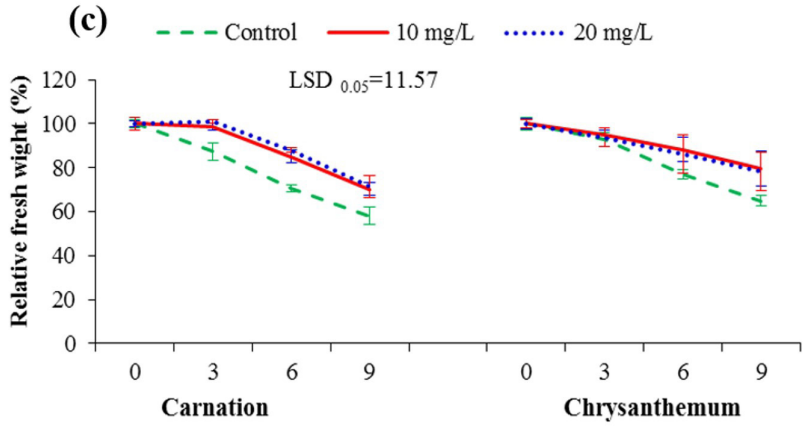

Vase period (days)

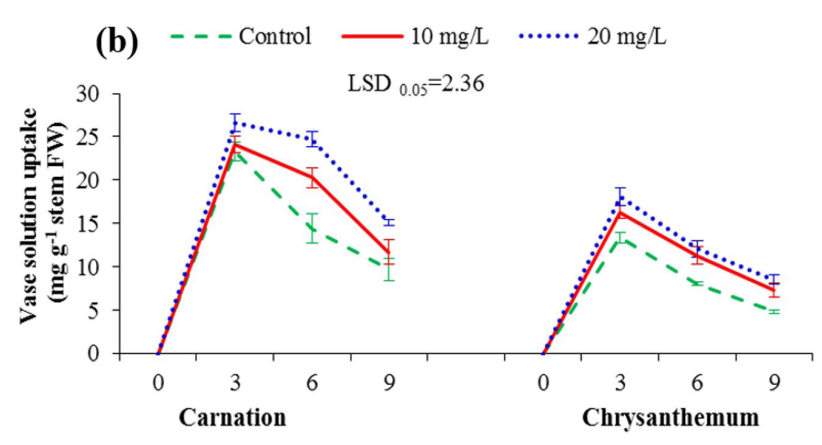

Vase period (days)

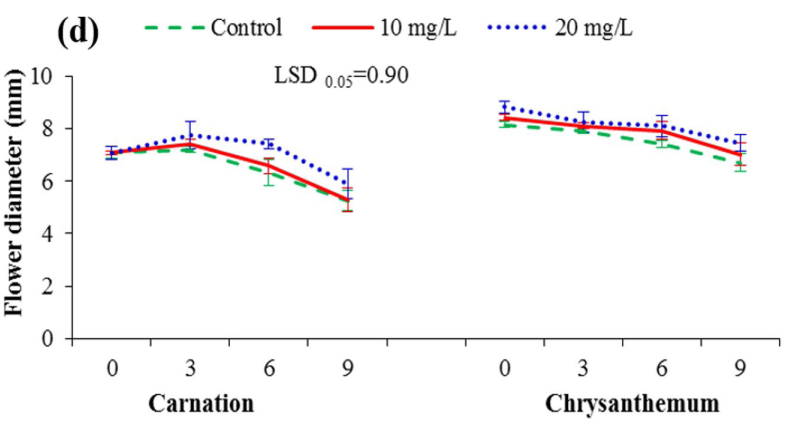

Vase period (days)

Figure 4. Effect of two concentrations of CuNPs (10 and $\left.20 \mathrm{mg} \mathrm{L}^{-1}\right)$ alongside the control (DIW) on bacterial population of the stem end (a), vase solution uptake (b), relative fresh weight (c), and flower diameter (d) of two cut flowers during vase life. Values represent means \pm standard error $(n=3)$. Least significant difference $(L S D)$ at $P \leq 0.05$ was used for means comparis 


\section{$\mathrm{H}_{2} \mathrm{O}_{2}$ and MSI}

There was a rise in the amount of $\mathrm{H}_{2} \mathrm{O}_{2}$ in control during the vase period. The trend of this increase was more prominent in carnation than in chrysanthemum. CuNPs caused a decrease in the rise of $\mathrm{H}_{2} \mathrm{O}_{2}$ in both cut flowers, but not to the extent that could stop its increment. Nonetheless, carnations that had been treated with CuNPs showed a significantly lower amount of $\mathrm{H}_{2} \mathrm{O}_{2}$ in comparison with that of the control group on the $9^{\text {th }}$ day of the vase period (Figure 5a).

The petals of flowers showed a declining trend in their mean values of MSI during the vase period. CuNPs somehow maintained the MSI in both cut flowers throughout the vase period compared to the control, although the concentrations of 20 and $10 \mathrm{mg} \mathrm{L}^{-1}$ appeared to be more suitable for carnation and chrysanthemum, respectively. On the $9^{\text {th }}$ day of the carnations vase period, both concentrations of CuNPs had caused a substantial effect on the MSI, the value of which differed significantly with the control. However, on the same day, only the $10 \mathrm{mg}$ $\mathrm{L}^{-1}$ had caused a substantial effect on the chrysanthemum to the extent of having a comparable difference with the control, and there were no significant differences between the two concentrations concerning this flower (Figure 5b).

In the present study and in control groups of both flowers, our results accorded closely with those reported by Hassan et al. (2014) on cut rose. Here, the increase in the amount of $\mathrm{H}_{2} \mathrm{O}_{2}$ coincided with the decrease in the amount of MSI. Interestingly, in carnation the amount of $\mathrm{H}_{2} \mathrm{O}_{2}$ almost doubled and the amount of MSI almost halved from day 0 to day 9 of the vase period. In the chrysanthemum, a similar increase in the amount of $\mathrm{H}_{2} \mathrm{O}_{2}(\sim 31 \%)$ was caused by the same decrease in MSI. The decrease in the MSI, as an index of membrane leakiness with senescence has also been reported on Hemerocallis (Panavas and Rubinstein, 1998) and Iris versicolor (Ahmad and Tahir, 2016). Celikel et al. (1995) reported that the senescence in carnation flowers can correlate with lipid peroxidation and that the beginning of the autocatalytic ethylene production can be inhibited by ROS scavengers. The high content of $\mathrm{H}_{2} \mathrm{O}_{2}$ in carnation in comparison with chrysanthemum may have pertained to the high sensitivity of carnation to ethylene, and therefore the use of CuNPs could significantly reduce the content of $\mathrm{H}_{2} \mathrm{O}_{2}$ even on day 9 of the vase period. Unlike carnation, the $\mathrm{H}_{2} \mathrm{O}_{2}$ content is lower in chrysanthemum due to its insensitivity to ethylene. Accordingly, the use of CuNPs did not make a significant difference in this regard on any day of the vase period.

\section{POD and SOD enzyme activates}

Carnation petals underwent a steady rise in POD activity during their vase period. This is comparable with the trend observed in chrysanthemum which increased until the $3^{\text {rd }}$ day and thereafter decreased until the $6^{\text {th }}$ day, but again increased until the end of the vase period. Enriching the vase solution of both cut flowers with CuNPs made the POD activity of treated samples be higher than that of untreated ones. By the $9^{\text {th }}$ day of the vase period, the concentration of $20 \mathrm{mg} \mathrm{L}^{-1}$ CuNPs had caused a significantly higher POD activity in comparison with the control in carnation. Regarding chrysanthemum, however, by the same day, both concentrations of 10 and $20 \mathrm{mg}$ $\mathrm{L}^{-1}$ had caused a significant difference in POD activity as compared to the control (Figure 5c).

There was a significant difference between the SOD activity in the petals of carnation and in those of chrysanthemum in their original states. In the beginning, the SOD activity was much higher in carnation in comparison to the chrysanthemum. As the vase period progressed, however, carnation petals underwent a more significant decrease in SOD activity in contrast to chrysanthemum petals. Compared to the control flowers, treatments with CuNPs caused a low activity of SOD. By the $9^{\text {th }}$ day of the vase period, unlike chrysanthemum, both concentrations of CuNPs on carnations had not managed to cause significant differences in the activity of SOD (Figure $5 d$ ).

In the current study, the increasing activity of SOD and POD in chrysanthemum caused the antioxidant defense system to be more reliable than the one observed in carnation (Figs. 10 and 11), thereby contributing to an increase in the MSI in chrysanthemum which had been treated with CuNPs, as compared to the control. Also, unlike in chrysanthemum, the SOD activity in carnation was more suppressed during the vase period, which could be seen as a support for previous observations by Sylvestre et al. (1989), where it was reported that the SOD activity decreased during petal development in carnation. Being in close accordance with our results on SOD activity in chrysanthemum, Hossain et al. (2006) showed that the SOD activity in Gladiolus (an ethylene-insensitive species) increased during flower senescence. Moreover, the CuNPs reduced the level of $\mathrm{H}_{2} \mathrm{O}_{2}$ in carnation flower petals as compared to the control (Figure 5a), which may be due to an increased activity of the POD which exploits the substrate of $\mathrm{H}_{2} \mathrm{O}_{2}$ and uses it for various reactions. The activity of $\mathrm{POD}^{2}$ is thus increased during senescence in carnation (Bartoli et al., 1995) and in daylily (Panavas and Rubinstein, 1998). 


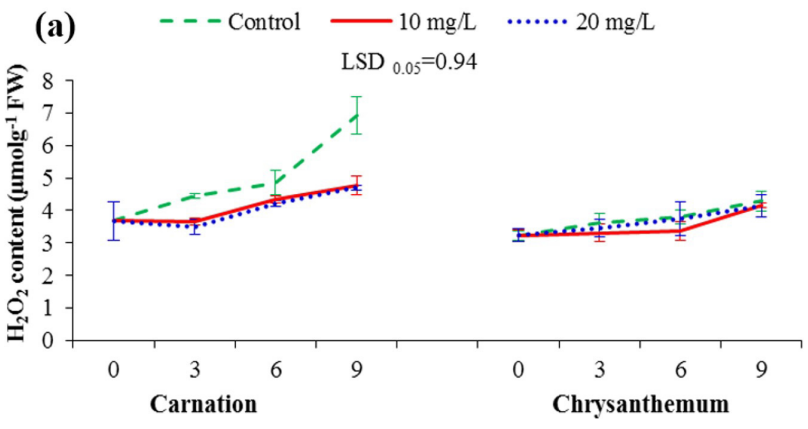

Vase period (days)

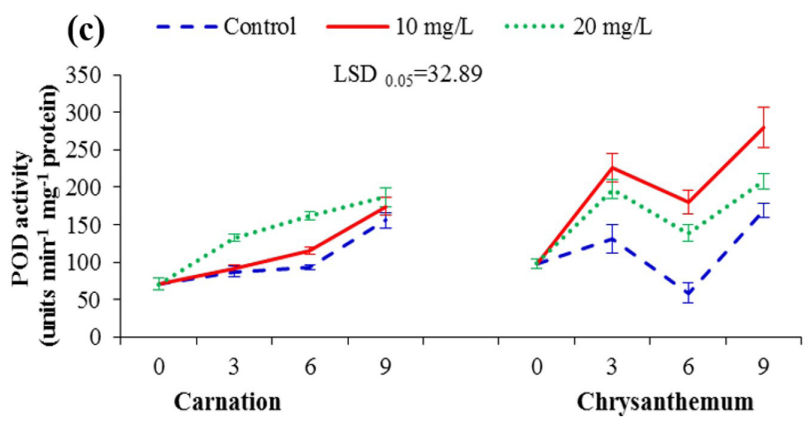

Vase period (days)

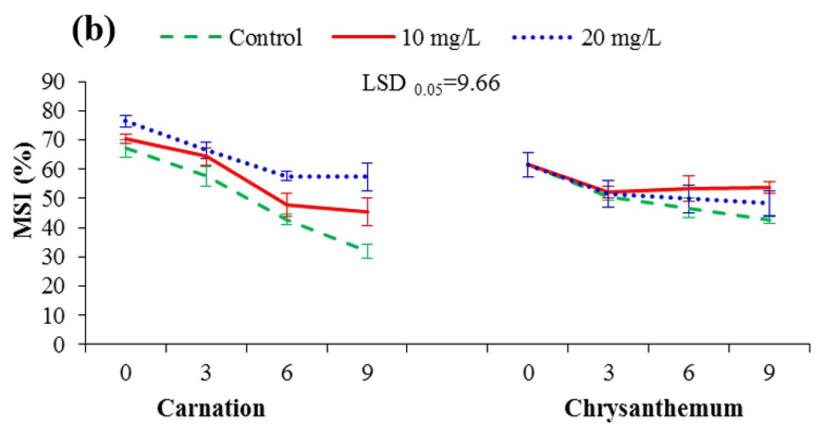

Vase period (days)

(d)

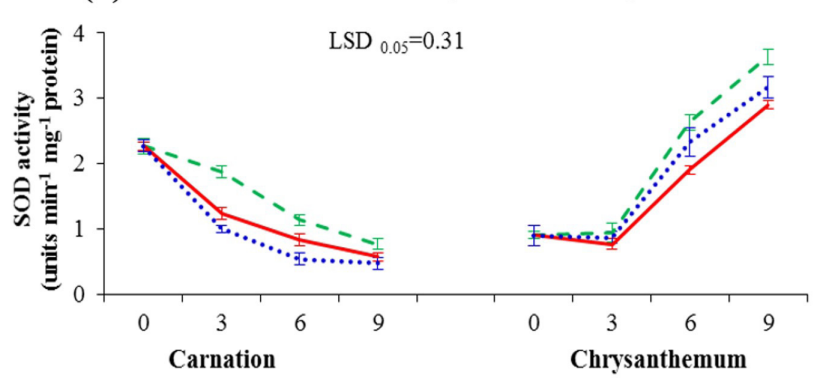

Vase period (days)

Figure 5. Effect of two concentrations of CuNPs $\left(10\right.$ and $\left.20 \mathrm{mg} \mathrm{L}^{-1}\right)$ alongside the control (DIW) on bacterial population of the stem end (a), vase solution uptake (b), relative fresh weight (c), and flower diameter (d) of two cut flowers during vase life. Values represent means \pm standard error $(n=3)$. Least significant difference (LSD) at $P \leq 0.05$ was used for means comparison.

\section{TSP and TSC}

In the beginning, the TSP content of petals in the chrysanthemum was three times more than that of the carnation in untreated samples. During the vase period, the TSP content in carnation petals increased in contrast to the chrysanthemum. The use of CuNPs in the vase solution of flowers made the TSP content of treated flowers become ultimately higher compared to the control. The concentrations of 20 and $10 \mathrm{mg} \mathrm{L}^{-1}$ were observed to be more effective in carnation and chrysanthemum, respectively. On the $9^{\text {th }}$ day of the vase period, both concentrations of CuNPs had already caused a significant effect on carnation in comparison to the control, but such difference was not remarkable in the case of chrysanthemum (Figure 6a).

The petals of carnations contained a higher amount of TSC compared to the petals of chrysanthemum at the beginning of the vase period, indicating a completely significant difference between the two flowers in their original states. In control flowers, the amount of TSC declined gradually during the vase period, which was more noticeable in chrysanthemum than in carnation. By adding the CuNPs into the vase solution, the amount of TSC increased in both cut flowers during the vase period, with carnation being more responsive than chrysanthemum. On the $9^{\text {th }}$ day, both concentrations of CuNPs had caused the treated and untreated carnations to differ significantly compared to each other in terms of their TSC, whereas no such significant differences were observed in the case of chrysanthemum (Figure 6b).
Senescence in flowers involves the degradation of proteins, lipids, carbohydrates, and nucleic acids (Tripathi and Tuteja, 2007). Our results revealed that lower levels of TSP in chrysanthemum could be linked to the same in Hemerocallis (Lay-Yee et al., 1992), Iris (Celikel and van Doorn, 1995), D. chinensis (Dar et al., 2014), peony (Zhao et al., 2018). Furthermore, Shahri et al. (2011) reported that the TSP is high at the time of flower opening in Helleborus orientalis cv. Olympicus. Nonetheless, the TSP decreases gradually when the flower reaches a stage of senescence due to higher levels of protease activity. In our study, both concentrations of CuNPs led to significantly higher TSP content in carnation than in the control after the third day of the vase period (Figure 6a). This increase in TSP in carnation may be due to the production of new proteins. The amount of TSP in the chrysanthemum was maintained at a relatively constant level by the third day, but then gradually decreased. However, both concentrations of CuNPs could not significantly increase the TSP in comparison with the control on day 9 (Figure 6a). This result is supported by a previous indication by Sharifzadeh et al. (2013) where it was concluded that $\mathrm{Cu}$ sulfate could increase the TSP content of lisianthus petals, however insignificantly. The reduction of protein content may be the result of less protein biosynthesis or a faster rate of protein degradation (Celikel and van Doorn, 1995). The increase in the amount of TSP in the petals of the two cut flowers, especially in carnation, was achieved by applying CuNPs (Figure 6a). Similar to 
this, Gao et al. (2008) reported that the protein content in the leaves and stems of Jatropha curcas L. seedlings increased significantly, compared to the control, by using 400 and $800 \mu \mathrm{mol}$ of $\mathrm{CuSO}_{4}$, respectively. The researchers concluded that the mechanism by which $\mathrm{Cu}$ affects protein content is complex and needs further evaluations.

According to our results about TSC in the control groups of both flowers (Figure 6b), Cavasini et al. (2018) reported that TSC decreases during senescence because of oxidative processes that occur in plants after harvest. Here, the application of CuNPs dramatically increases the TSC content in carnation, compared with chrysanthemum (Figure 6b). This may be due to the high sensitivity of carnation to ethylene, and the fact that CuNPs may have a role in reducing ethylene levels and respiration, thereby leading to lower levels of carbohydrate consumption. Also, there were higher values of VSU and, consequently, enhanced levels of RFW among samples treated with CuNPs. Here, the TSC increased in both cut flowers. In addition, the CuNPs may be capable of activating some enzymes involved in photosynthesis, thereby increasing the TSC (Cook et al., 1997). Our results accord with those reported by Pun and Ichimura (2003) who found that extending the vase life can be in line with treatments that maintain the levels of carbohydrates in cut flowers.
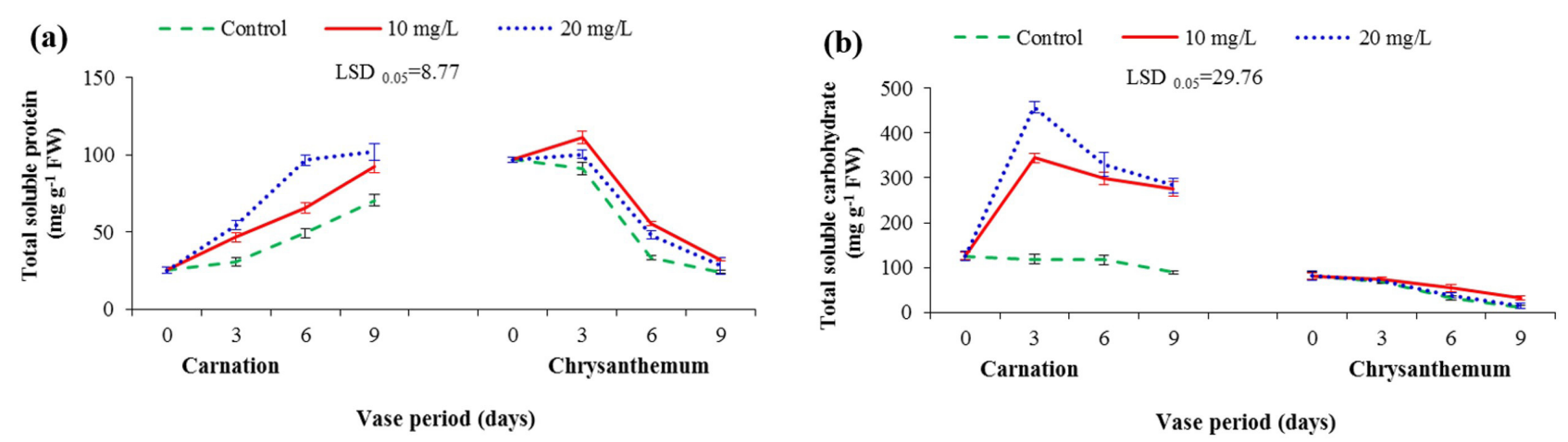

Figure 6. Effect of two concentrations of CuNPs (10 and $\left.20 \mathrm{mg} \mathrm{L}^{-1}\right)$ alongside the control (DIW) on total soluble protein (a) and total soluble carbohydrate (b) of two cut flowers species during vase life. Values represent means \pm standard error $(n=3)$. Least significant difference (LSD) at $\mathrm{P} \leq 0.05$ was used for means comparison.

\section{Conclusions}

In the present study, the pulse treatment of CuNPs had positive effects on FD, RFW, VSU, MSI, TSC, $\mathrm{H}_{2} \mathrm{O}_{2}$, TSC and TSP as well as had a fundamental role in inhibiting the growth of bacterial population of the stem end. These effects are also observed in activities of POD and SOD which, in turn, can ultimately prolong the vase life of the two cut flowers significantly, as compared with the control. In conclusion, using the pulsing treatment by CuNPs at $20 \mathrm{mg} \mathrm{L}^{-1}$ is recommended when aiming at prolonging the vase life of chrysanthemum and carnation.

\section{Author Contribution}

NR, FN ${ }^{0000-0001-5671-6188 ~ a n d ~ T J: ~ e x p e r i m e n t a l ~ d e s i g n, ~ e x e c u t i o n, ~}$ data analysis and writing the manuscript. SS was responsible for producing the CuNPs.

\section{Acknowledgements}

The authors wish to thank the University of Kurdistan for providing facilities and financial support (Grant No. CRC9700242-1) for this research.

\section{References}

AHMAD, S.S.; TAHIR, I. Increased oxidative stress, lipid peroxidation and protein degradation trigger senescence in Iris versicolor L. flowers. Physiology and Molecular Biology of Plants, v.22, p.2016507-514, 2016.

ALEXIEVA, V.; SERGIEV, I.; MAPELLI, S.; KARANOV, E. The effect of drought and ultraviolet radiation on growth and stress markers in pea and wheat. Plant, Cell and Environment, v.24, p.1337-1344, 2001.

AVERY, S.V.; HOWLETT, N.G.; RADICE, S. Copper toxicity towards Saccharomyces cerevisiae: dependence on plasma membrane fatty acid composition. Applied and Environmental Microbiology, v.62, p.3960-3966, 1996.

BALESTRA, G.M.; AGOSTINI, R.; BELLINCONTRO, A.; MENCARELLI, F.; VARVARO, L. Bacterial populations related to gerbera (Gerbera jamesonii L.) stem break. Phytopathologia Mediterranea, v.44, p.291-299, 2005. 
BARTOLI, C.G.; SIMONTACCHI, M.; GUIAMET, J.J.; MONTALDI, E. Antioxidant enzymes and lipid peroxidation during aging of Chrysanthemum morifolium RAM petals. Plant Science, v.104, p.161-8, 1995.

BEYER, W.F.; FRIDOVICH, I. Assaying for superoxide dismutase activity: some large consequences of minor changes in conditions. Analytical Biochemistry, v.161, p.559-566, 1987.

BRADFORD, M.M. A rapid and sensitive method for the quantitation of microgram quantities of protein utilizing the principle of protein-dye binding. Analytical Biochemistry, v.72, p.248-254, 1976.

CARRILLO-LÓPEZ， L.M.; MORGADO-GONZÁLEZ, M.; MORGADO-GONZÁLEZ, A. Biosynthesized silver nanoparticles used in preservative solutions for Chrysanthemum cv. Puma. Nanomaterials, p.1-10, 2016.

CAVASINI, R.; LASCHI, D.; TAVARES, A.R.; LIMA, G.P.P. Carbohydrate reserves on postharvest of lisianthus cut flowers. Ornamental Horticulture, v.24, p.12-18, 2018.

CELIKEL, F.G.; JOYCE, D.C.; FARAGHER, J.D. Inhibitors of oxidative enzymes affect water uptake and vase life of cut Acacia holosericea and Chamelaucium uncinatum stems. Postharvest Biology and Technology, v.60, p.149-157, 2011.

CELIKEL, F.G.; VAN DOORN, W.G. Solute leakage, lipid peroxidation, and protein degradation during the senescence of Iris tepals. Physiologia Plantarum, v.94, p.515-521, 1995.

COOK, C.M.; KOSTIDOU, A.; VARDAKA, E.; LANARAS, T. Effects of copper on the growth, photosynthesis and nutrient concentrations of Phaseolus plants. Photosynthetica, v. 34, p.179-193, 1997.

DAR, R.A.; TAHIR, I.; AHMAD, S.S. Physiological and biochemical changes associated with flower development and senescence in Dianthus chinensis L. Indian Journal of Plant Physiology, v.19, p.215-221, 2014.

GAO, S.; YAN, R.; CAO, M.; YANG, W.; WANG, S.; CHEN, F. Effects of copper on growth, antioxidant enzymes and phenylalanine ammonialyase activities in Jatropha curcas L. seedling. Plant, Soil and Environment, v.54, p.117-122, 2008.

HALEVY, A.H.; MAYAK, S. Senescence and postharvest physiology of cut flowers-Part 2. Horticultural Reviews, v.3, p.59-143, 1981.
HASSAN, F.A.S.; ALI, E.F.; EL-DEEB, B. Improvement of postharvest quality of cut rose cv. First Red by biologically synthesized silver nanoparticles. Scientia Horticulturae, v.179, p.340-348, 2014.

HE, S.; JOYCE, D.C.; IRVING, D.E.; FARAGHER, J.D. Stem end blockage in cut Grevillea 'Crimson Yul-1o' inflorescences. Postharvest Biology and Technology, v.41, p.78-84, 2006.

HEMEDA, H.M.; KLEIN, B. Effects of naturally occurring antioxidants on peroxidase activity of vegetable extracts. Journal of Food Science, v.55, p.184-185, 1990.

HOSSAIN, Z.; MANDAL, A.K.A.; DATTA, S.K.; BISWAS, A.K. Decline in ascorbate peroxidase activity-a prerequisite factor for tepal senescence in gladiolus. Journal of Plant Physiology, v.163, p.186-194, 2006.

IRIGOYEN, J.; EINERICH, D.; SÁNCHEZ-DÍAZ, M. Water stress induced changes in concentrations of proline and total soluble sugars in nodulated alfalfa (Medicago sativa) plants. Physiologia Plantarum, v.84, p.55-60, 1992.

KIM, S.H.; KRONSTAD, J.W.; ELLIS, B.E. Purification and characterization of phenylalanine ammonia-lyase from Ustilago maydis. Phytochemistry, v.43, p.351-357, 1996.

LAY-YEE, M.; STEAD, A.D.; REID, M.S. Flower senescence in daylily (Hemerocallis). Physiologia Plantarum, v.86, p.308-314, 1992.

LIU, J.; HE, S.; ZHANG, Z.; CAO, J.; LV, P.; HE, S.; CHENG, G.; JOYCE, D.C. Nano-silver pulse treatments inhibit stem-end bacteria on cut gerbera cv. Ruikou flowers. Postharvest Biology and Technology, v.54, p.59$62,2009$.

LOUBAUD, M.; VAN DOORN, W.G. Wound-induced and bacteria-induced xylem blockage in roses, Astilbe and Viburnum. Postharvest Biology and Technology, v.32, p.281-288, 2004.

LU, P.; CAO, J.; HE, S.; LIU, J.; LI, H.; CHENG, G.; DING, Y.; JOYCE, D.C. Nano-silver pulse treatments improve water relations of cut rose cv. Postharvest Biology and Technology, v.57, p.196-202, 2010.

NACZK, M.; SHAHIDI, F. Extraction and analysis of phenolics in food. Journal of Chromatography, v.1054, p.95-111, 2004.

NAING, A.H.; WIN, N.M.; HANG, J.S.; LIM, K.B.; KIM, C.K. Role of nanosilver and the bacterial strain Enterobacter cloacae in increasing vase life of cut carnation 'Omea'. Front Plant Science, v.8, p.1590, 2017. 
PANAVAS, T.; RUBINSTEIN, B. Oxidative events during programmed cell death of daylily (Hemerocallis hybrid) petals. Plant Science, v.133, p.25-138, 1998.

PUN, U.K.; ICHIMURA, K. Role of sugars in senescence and biosynthesis of ethylene in cut flowers. Japan Agricultural Research Quarterly, v.37, p.219-244, 2003.

RAFFI, M.; MEHRWAN, S.; BHATTI, T.; AKHTER, J.; HAMEED, A.; YAWAR, W.; HASAN, M. Investigations into the antibacterial behavior of copper nanoparticles against Escherichia coli. Annals of Microbiology, v.60, p.75-80, 2010.

RATNAYAKE, K.; BUI, C.L.; JOYCE, D.C. Copper distribution and ionic form effects for postharvest treatments of cut Acacia holosericea stems. Scientia Horticulturae, v.130, p.919-926, 2011.

RATNAYAKE, K.; JOYCE, D.C.; WEBB, R.I. Investigation of potential antibacterial action for postharvest copper treatments of cut Acacia holosericea. Postharvest Biology and Technology, v.70, p.59-69, 2012.

REID, M.S.; JIANG, C.Z. Postharvet biology and technology of cut flowers and potted plants. Horticultural Reviews, v.40, p.1-54, 2012.

SAIRAM, R.K.; RAO, K.V.; SRIVASTAVA, G. Differential response of wheat genotypes to long term salinity stress in relation to oxidative stress, antioxidant activity and osmolyte concentration. Plant Science, v.163, p.10371046, 2002.

SANKAT, C.K.; MUJAFFAR, S. Water balance in cut anthurium flowers in storage and its effect of quality. Acta Horticulturae, v.368, p.723-732, 1994.

SHAHRI, W.; TAHIR, I.; ISLAM, S.T.; BHAT, M.A. Physiological and bio-chemical changes associated with flower development and senescence in so far unexplored Helleborus orientalis Lam. cv. Olympicus. Physiology and Molecular Biology of Plants, v.17, p.33-39, 2011.

SHARIFZADEH, K.; HASSANPOUR ASIL, M.; ROEIN, $Z$. Effect of copper sulphate on enzyme activity and vase life of lisianthus cut flower. International Journal of Horticultural Science and Technology, v.14, p.219-228. 2013. (in Persian with English abstract).

SUN, T.; YAN, Y.; ZHAO, Y.; GUO, F.; JIANG, C. Copper oxide nanoparticles induce autophagic cell death in A549 cells. PLoS ONE, v.7, n.8, p.e43442, 2012. https://doi. org/10.1371/journal.pone.0043442.
SYLVESTRE, I.; DROILLARD, M.J.; BUREAU, J.M.; PAULIN, A. Effects of the ethylene rise on the peroxidation of membrane lipids during the senescence of cut carnations. Plant Physiology and Biochemistry, v.27, p.407-413, 1989.

TRAN, N.; MIR, A.; MALLIK, D. Bactericidal effect of iron oxide nanoparticles on Staphylococcus aureus. International Journal of Nanomedicine, v.5, p.277-283, 2010 .

TRIPATHI, A.; GAUTAM, M. Biochemical parameters of plants as indicators of air pollution. Journal of Environmental Biology, v.28, p.127, 2007.

UMER, A.; NAVEED, S.; RAMZAN, N.; RAFIQUE, M.S.; IMRAN, M. A green method for the synthesis of copper nanoparticles using L-ascorbic acid. Materia, v.19, p.197-203, 2014.

VAN DOORN, W.G.; CRUZ, P. Evidence for a woundinginduced xylem occlusion in stems of cut chrysanthemum flowers. Postharvest Biology and Technology, v.19, p.73$83,2000$.

VAN DOORN, W.G.; VASLIER, N. Wounding-induced xylem occlusion in stems of cut chrysanthemum flowers, roles of peroxidase and cathechol oxidase. Postharvest Biology and Technology, v.26, p.275-284, 2002.

VAN MEETEREN, U.; VAN GELDER, H.; VAN IEPEREN, W. Reconsideration of the use of DIW as vase water in postharvest experiments on cut flowers. Postharvest Biology and Technology, v.17, p.175-187, 1999.

WITTE, Y.; VAN DOORN, W.G. The mode of action of bacteria in the vascular occlusion of cut roses flowers. Acta Horticulturae, v.298, p.165-167, 1991.

ZHAO, D.; CHENG, M.; TANG, W.; LIU, D.; ZHOU, S.; MENG, J.; TAO, J. Nano-silver modifies the vase life of cut herbaceous peony (Paeonia lactiflora Pall.) flowers. Protoplasma, v.1, p.1-13, 2018. 